\title{
HUBUNGAN ANTARA KONFORMITAS TEMAN SEBAYA DENGAN MOTIVASI BERPRESTASI KELAS VII MTS BUDAYA LANGKAT TAHUN PELAJARAN 2019/2020
}

\author{
Rini Aulia ${ }^{1}$, Nurul Hasanah ${ }^{2}$ \\ Program Studi Pendidikan Bimbingan dan Konseling STKIP Budidaya Binjai, Indonesia \\ E-mail:riniaulia380@gmail.com
}

\begin{abstract}
ABSTRAK
Penelitian ini bertujuan untuk mengetahui hubungan antara konformitas teman sebaya dengan motivasi berprestasi kelas VII MTs Budaya Langkat tahun pelajaran 2019/2020. Jenis penelitian ini kuantitatif. subjek dalam penelitian ini adalah 25 orang siswa kelas VII. Instrumen yang digunakan adalah konformitas teman sebaya dan Motiasi berprestasi. Dari 50 item skala konformitas yang di uji terdapat 50 item yang valid, sedangkan skala motivasi 50 item skala yang di uji terdapat 9 item yang tidak valid. Objek nya adalah kelas VII MTs Budaya Langkat. Dari hasil penelitian yang didapat subjek yang berjenis perempuan berjumlah 17 orang laki-laki 8 orang. Berdasarkan deskripsi diketahui hubungan antara konformitas teman sebaya dengan motivasi berprestasi adalah $\mathrm{P}>0,007$ yang mana terdapat penelitian pengaruh hubungan antara konformitas teman sebaya dengan motivasi berprestasi. Penelitian adalah uraian tentang hal-hal yang berkaitan dengan proses kegiatan penelitian. Berdasarkan hasil penelitian yang telah dilakukan, maka dapat disimpulkan bahwa ada hubungan yang sangat signifikan antara hubungan konformitas teman sebaya dengan motivasi berprestasi, hal ini dibuktikan dengan nilai hasil koefisien korelasi yang menunjukan angka 0,523 dengan nilai sig 0,007 dimana $p<0,05$. Artinya semakin tinggi hubungan antara konformitas teman sebaya maka semakin baik motivasi berprestasi. Sebaliknya, semakin rendah hubungan antara konformitas teman sebaya dengan motivasi berprestasi semakin rendah.
\end{abstract}

\section{Kata Kunci: Konformitas Teman sebaya, Motivasi berprestasi}




\section{PENDAHULUAN}

Siswa adalah salah satu komponen manusiawi yang menempati posisi sentral dalam prosesbelajar mengajar, siswa sebagai pihak yang ingin meraih cita-cita, memiliki tujuan dan ingin mencapainya secara optimal. Siswa akan menjadi faktor penentu, sehingga dapat mempengaruhi segala sesuatu yang dipengaruhi segala sesuatu yang di perlukan untuk mencapai tujuan belajarnya.

Siswa adalah organisme yang untuk berkembang sesuai dengan tahap Perkembangan. Perkembangan anak adalah perkembangan seluruh aspek kepribadianya, akan tetapi tempo dan irama perkembangan masing- masing anak pada setiap aspek tidak selalu sama. Hal yang sama siswa juga dapat dikatakan sebagai sekelompok orang dengan usia tertentu belajar baik secara kelompok atau perorangan.

\subsection{Pengertian motivasi}

Pengertian motivasi merupa-

kan bagian penting dalam setiap kegiatan, termasuk aktivitas belajar, tanpa motivasi tidak ada kegiatan yang nyata. Menurut Robbin, (Wamotivasi adalah kemauan untuk mengerjakan sesuatu. Kemauan tersebut nampak pada usaha seseorang untuk mengerjakan sesuatu, namun motivasi bukan perilaku. Motivasi merupakan proses internal yang kompleks yang tidak bisa diamati secara langsung, Melainkan bisa dipahami melalui kerasnya seseoang dalam mengerjakan sesuatu.

\subsection{Pengertian konformitas}

Pengertian Konformitas adalah terjadi ketika individu mengubah tingkah laku mereka dengan tujuan untuk mentaati norma sosial yang ada. Konformitas bagi remaja atau individu yang berusia muda dan yang tidak berpengalaman lebih muda dipengaruhi oleh apa yang dianggap kelompok remaja sebagai cara yang terbaik dari pada pendirian individu itu sendiri. Pengertian Konformitas adalah terjadi ketika individu mengubah tingkah laku mereka dengan tujuan untuk mentaati norma sosial yang ada. Konformitas bagi remaja atau individu yang berusia muda dan yang tidak berpengalaman lebih muda dipengaruhi oleh apa yang dianggap kelompok remaja sebagai cara yang terbaik dari pada pendirian individu itu sendiri.

Menurut Baron, juga menyatakan bahwa individu konformitas terhadap kelompok teman atau masyarakat. Baron dan Byrne menambahkan bahwa konformitas remaja adalah penyesuaian perilaku remaja untuk menganut pada norma kelompok acuan, menerima ide atau aturan-aturan yang menunjukkan bagaimana remaja berperilaku. Berdasarkan uraian diatas maka dapat disimpulkan bahwa konformitas adalah suatu bentuk penyesuaian diri dengan cara meniru sikap atau tingkah laku orang lain dikarenakan tekanan yang nyata atau tidak.

Kelompok teman sebaya menjadi sangat berarti dan berpengaruh dalam kehidupan sosial remaja karena menjadi tempat untuk belajar kecakapan- kecakapan sosial serta mengambil berbagai peran. Di dalam kelompok teman sebaya, remaja menjadi sangat bergantung kepada teman sebagai sumber kesenangannya dan keterikatnya dengan teman sebaya begitu kuat.

Mungkin khususnya pada MTs Budaya Langkat, seharus nya sudah memahami apa itu konformitas yang berbentuk pengaruh sosial di mana individu mengubah sikap dan tingkah lakunya agar sesuai dengan norma sosial, dan bisa bergaul dengan kelompok teman sebaya dengan baik dan menjauhi hal-hal yang merugikan siswa. 
tindakan walaupun remaja tidak menginginkannya.

\subsection{Faktor-Faktor}

\section{Konformitas Teman Sebaya}

(Baron \& Bryne, 2005).

a. Kohesivitas dan Konformitas Kohesivitas merupakan derajat ketertarikan yang dirasa oleh individu terhadapsuatu kelompok.

b.Konformitas dan ukuran kelompok c.Faktorkedua yang memiliki

kecenderungan untuk melakukan konformitas adalah ukuran dari kelompok yang berpengaruh.

d.Norma Sosial Deskriptif dan Norma

Sosial Injungtif

Norma deskriptif adalah Norma yang hanya mendeskripsikan apa yang sebagian besar orang lakukan pada situasi tertentu. Sedang kan norma injungtif menetapkan apa yang harus dilakukan dan tingkah laku apa yang diterima atau yang tidak diterima pada situasi tertentu.

\subsection{Aspek-aspek Konformitas \\ Tem- man Sebaya}

Konformitas sebuah kelompok acuan dari mudah terlihat dengan adanya ciri-ciri yang khas Sears, dkk mengemukakan secara eksplisit aspek konformitas berdasarkan adanya ciri- ciri yang khas sebagai berikut :

\section{Kekompakkan}

Kekuatan yang dimiliki kelompok acuan menyebab kan remaja tertarik dan ingin tetap menjadi anggota kelompok.

2. Kesepakatan

Pendapat kelompok acuan yang sudah dibuat memiliki tekanan kuat sehingga remaja dapat menyesuaikan pendapatnya dengan pendapat kelompok

Tekanan kelompok membuat adanya kesepakatan dalam kelompok tersebut.

3. Ketaatan

Tekanan atau tuntutan kelompok acuan pada remaja membuatnya rela melakukan

\subsection{Aspek/ Komponen Motivasi}

\section{Berprestasi}

Aspek motivasi berprestasi yang tinggi menurut Mc Clelland yaitu:

a. Tanggung jawab b.Mempertimbangkan resiko pemili- han tugas

c. Memperhatikan umpan balik

d. Kreatif dan Inovatif

e. Waktu penyelesaian tugas

f. Keinginan menjadi yang terbaik

\section{METODE PENELITIAN}

Jenis penelitian yang digunakan dalam penelitian ini adalah penellitian

kuantitatif Penelitian kuantitatif adalah metode penelitian yang berlandaskan terhadap filsafat positivisme, digunakan dalam meneliti terhadap sample dan populasi penelitian. Dalam penelitian ini terdapat dua variabel yaitu : 1.Variabel bebas (X) yaitu Konform- itas teman sebaya

2. Variabel terikat (Y) yaitu Motivasi berprestasi.

\section{HASIL PEMBAHASAN}

\section{A. Subjek Penelitian}

Deskripsi subjek penelitian dilakukan dengan tujuan agar mengetahui Hubungan antara konformitas teman sebaya dengan motivasi berprestasi kelas VII MTs Budaya Langkat tahun pelajaran 2019/2020.

Tabel 1. subjek penelitian

\begin{tabular}{lccc}
\hline No & $\begin{array}{c}\text { Jenis } \\
\text { kelamin }\end{array}$ & Jumlah & $\begin{array}{c}\text { Persen } \\
\mathbf{\%}\end{array}$ \\
\hline 1. & Perempuan & 17 & $70 \%$ \\
\hline 2. & Laki - Laki & 8 & $30 \%$ \\
\hline & Jumlah & & $100 \%$ \\
\hline
\end{tabular}




\section{B. Uji Standart Normalitas}

Uji normalitas dilakukan untuk mengetahui apakah distribusi data penelitian setiap variabel telah menyebar secara normal.

Uji normalitas dilakukan dengan metode satistik menggunakan program SPSS Version 20.0.

\section{Uji Linearitas}

Uji Linearitas bertujuan untuk mengetahui apakah dua variabel mempunyai hubungan yang linear atau tidak secara signifikan.

\section{Hasil Hipotesis}

Hasil penelitian dilakukan untuk menguji hipotesis penelitian yang mana hipotesis penelitian yang mana hipotesis penelitan adalah :

1) Ho : menolak ada hubungan yang tinggi atau rendah hubungan antara konformitas teman sebaya dengan motivasi berprestasi.

2) Ha : menerima hubungan yang tinggi atau rendah hubungan antara konformitas teman sebaya dengan motivasi berpretasi.

Berikut adalah hasil penelitian hubungan antara konformitas teman sebaya dengan motivasi berprestasi.

Tabel 2. Correlations

\begin{tabular}{rlrr}
\hline & & \multicolumn{1}{c}{$\begin{array}{c}\text { KONFOR } \\
\text { MITAS }\end{array}$} & \multicolumn{2}{c}{ MOTIVASI } \\
\hline \multirow{5}{*}{ Konfomitas } & Pearson & 1 &, $523^{* *}$ \\
& Correlation & &, 007 \\
& Sig. (2- & & \\
& tailed) & & \\
& N & 25 & 25 \\
& Pearson &, $523^{* * *}$ & 1 \\
Motivasi & Correlation & & \\
& Sig. (2- &, 007 & \\
& tailed) & & \\
& N & 25 & 25 \\
\hline
\end{tabular}

Dari tabel diatas dapat diketahui bahwa nilai korelasinya adalah 0,007 yang $\mathrm{P}<0,05$ maka yang artinya Ho menolak bahwa terdapat hubungan antara konformitas teman sebaya dengan motivasi berprestasi.

Dari tabel diatas dapat diketahui bahwa nilai korelasinya adalah 0,007 yang $\mathrm{P}<0,05$ maka yang artinya Ho menolak bahwa terdapat hubungan antara konformitas teman sebaya dengan motivasi berprestasi.

\section{E. Hasil Penilitian}

Dari hasil penelitian yang didapat subjek 25 orang. Berdasarkan hasil deskripsi diketahui hubungan antara konformitas teman sebaya dengan motivasi berprestasi adalah $\mathrm{P}>0,007$ yang mana terdapat penelitian hubungan antara konformitas teman sebaya dengan motivasi berprestasi. Penelitian adalah uraian tentang hal-hal yang berkaitan dengan proses kegiatan penelitian. Oleh karena itu isi laporan penelitian bukan hanya langkah-langkah yang telah dilakukan oleh peneliti saja.

\section{KESIMPULAN}

Berdasarkan hasil penelitian yang telah dilakukan, maka dapat disimpulkan bahwa ada hubungan yang sangat signifikan antara hubungan konformitas teman sebaya dengan motivasi berprestasi, hal ini dibuktikan dengan nilai hasil koefisien korelasi yang menunjukan angka 0,523 dengan nilai sig 0,007 dimana $p<0,05$. Artinya semakin tinggi hubungan antara konformitas teman sebaya maka semakin baik motivasi berprestasi. Sebaliknya, semakin rendah hubungan antara konformitas teman sebaya dengan motivasi berprestasi semakin rendah. 


\section{DAFTAR PUSTAKA}

Ayu Lestari, Karina dkk. hubungan antara konformitas dengan motivasi belajar pada siswa di SMA Muhammadiyah Kudus, universitas Diponegoro. Jurnal. 2016.

Dasiemi,Emi dkk. Kenakalan Remaja, Ditinjau Dri Peresepsi Remaja,Terhadap Keharmonisan Keluarga Dan Konformitas Teman Sebaya,Universitas Sebelas Maret. Jurnal. 2010.

Fauziah,syifah dkk. Pengaruh Trait Keperibadian BIG FIVE Dan Konformitas Teman Sebaya Terhadap Agresivitas Anak PUNK Di Jabodetabek. Universitas Islam Negeri (UIN) syarif Hidayatullah jakarta. Jurnal.

Fachlevi,Yusi.Pengauh minat menjadi guru terhadap kepuasan kerja guru, Sekolah Tinggi Kegurruan Dan Ilmu Pendidikan (STKIP). Skripsi. 2018.

Hariyani,Ratna. Hubungan Berprestasi Pada Mahasiswa Berprestasi Dari Keluarga Tidak Mampu Secara Ekonomi. Fakultas Psikologi Universitas Airlangga. Jurnal. 2014.
Khairani, Makmun. Psikologi Belajar. Sleman Yogyakarta: perpustakaan Nasional RI.

Nurhidayati,Motivasiberprestasi,eprints.ums.ac.i d. Jurnal. 2017.

Sakinah,Indah. Hubungan antara konformitas teman sebaya dengan konsep diri siswa, Sekolah Tinggi Keguruan Dan Ilmu Pendidikan (STKIP). Skripsi. 2017.

Saputro, Bayu Mardi. Dkk. Hubungan antara Konformitas Teman Sebaya Dengan Kecenderungan Kenakalan Remaja, Universitas Marcua Buana Yogyakarta. Jurnal.2012.

Sugiono, Mitode penelitian kuantitatif, kualitatif. (Bandung :Alfabeta 2017).

W. Sarwono, Sarlito. dkk. 2017. Psikologi Sosial. Jakarta : Salemba Humanika. 